\title{
Epstein-Barr Early D Antigen IgG Antibody Measurement
}

National Cancer Institute

\section{Source}

National Cancer Institute. Epstein-Barr Early D Antigen Ig G Antibody Measurement. NCI

Thesaurus. Code C122116.

The determination of the amount of Epstein-Barr early D antigen Ig G antibody in a biological specimen. 